\title{
Identification of physical problems of major palm leaf manuscripts collections in Sri Lanka.
}

\section{C.N.K. Alahakoon}

\section{BA (Hons) Peradeniya., MLS(Colombo) \\ Senior Assistant Librarian University of Peradeniya}

\begin{abstract}
A survey of the largest collection of palm-leaf manuscripts was carried out in order to find out its maintenance, flaws, problems relating to the preservation and conservation programmes in Sri Lanka. Altogether, 717 manuscripts were taken to study the collections. The main research tools were a record sheet, a self administered questionnaire followed by interviews. $10 \%$ of each collection was selected as samples of the study and a simple random sampling method was applied. Data analysis was done by using SPSS statistical analysis package. The survey of visual observation and the viva-voce interviews revealed that most flaws of the manuscripts have taken place due to lack of awareness of the condition of the storage area, lack of experts in the field and insufficient equipment to control the hazards of the environment of the stack areas of some repositories. In the management process, application of new technology is not much practiced due to non availability of the infrastructure and the trained personnel in these repositories. The significant finding of the study revealed that a workable preservation and conservation policies and establishment of conservation units and cleaning programmesare needed.
\end{abstract}

\section{Introduction}

There are large collections of palm-leaf manuscripts available in libraries, museums and temples in Sri Lanka and it is a traditional practice to keep the enshrine books, manuscripts and other precious materials in temples, which are the centers of Buddhism in ancient Ceylon.

The largest collection of palm-leaf manuscripts is available in the Colombo Museum Library. At present, there are over 3,000 manuscript volumes $(6,000$ manuscripts) including the copy of the oldest so far discovered namely the "Cullavagga" text of the Vinaya Pitaka of the $13^{\text {th }}$ century deposited in this library. (Amarakoon, 1996). This precious collection consists of information on Buddhist canon, Sinhalese Literature, Prose and Verse, History and Tradition, Grammar 
and lexicography, Art, Indigenous Medicine and Veterinary Science, Astrology, Demonology, Science, Architecture, and Folk- lore.

University of Peradeniya has the second largest collection of palm-leaf manuscripts approximately 2300 manuscript volumes (exceeding 4800 manuscripts). This includes the $13^{\text {th }}$ century Vissuddhi Magga Tika (Wickremaratne, 1967) and a large collection of Buddhism, History and Geography- Magic and Charms, Art both Prose and Verse and Grammar, Lexicography and Prosody.

To the students of Ceylon History, a source of first hand information is available in manuscripts on incidents and manuscripts on demarcations and boundary, which are deposited in the National Archives, Colombo. A copy of Deepavamsa, which was compiled in the $14^{\text {th }}$ century and an ancient manuscript on Acupuncture, large amount of manuscripts relating to births, deaths and registration are also deposited and altogether there are about 1,000 manuscript volumes in this collection.

Among the variety of library and archival materials, palm-leaf manuscripts are scarce, valuable and irreplaceable. If neglected, their conservation would be a time consuming process. Manuscripts which are made of palm-leaves are some kind of a special material, which is considered as historically valuable research material whose physical preservation, is deemed to be essential and have to be protected more carefully.

\section{Objectives of the study}

The primary objective of this research was to study the present condition of the collections of palm-leaf manuscripts of the selected 3 repositories. The specific objectives were as follows:

- Understand the maintenance problem pertaining to the collections.

- Determine the extent of the preservation and conservation problems relating to the libraries.

- Study the existing preservation programmes in the libraries.

- To make suggestions to maximise the life of the collections.

\section{Methodology}

The visual observation, interviews and survey method was applied to collect the data.

\section{Selection criteria of the sample}

Since the total population consisted 7182 of manuscripts in these 3 repositories, (National Museum (3822), University of Peradeniya library (2326), and Department of National Archives (1034) $10 \%$ of the sample was selected randomly. 


\begin{tabular}{|c|l|c|c|}
\hline Repository & \multicolumn{1}{|c|}{ Library / Department } & Collection & $\begin{array}{c}\text { Sample } \\
10 \%\end{array}$ \\
\hline NM & Department of National Museums & 3822 & 382 \\
\hline UP & University of Peradeniya & 2326 & 232 \\
\hline NA & Department of National Archives & 1034 & 103 \\
\hline & Total & 7182 & 717 \\
\hline
\end{tabular}

\section{Data collection}

The maintenance problems were identified by using a questionnaire and it included availability of equipment, trained staff, space, chemicals, and financial allocation. A record sheet was prepared to check the physical condition of the manuscripts such as stains, surface discoloration, presence of fungi, insect damage, torn, edge damages, water patches, splits or peeling on the surface, cleavage of the surface layer, brittleness, fading of writing, rigid/flexibility of leaves, whether the leaves seasoned with resin oil, leaves curled, flaking, blackened and leaves stuck together etc. A further survey was carried out to identify whether pagination was in order and any repair carried out before. These flaws of palm-leaves were identified by using a work sheet and the reasons for the damages were also identified. Face to face interviews with the conservation units and with the conservators of the repositories were conducted to identify the preservation programmes of the repositories.

The environmental background of the storage system was observed and all data were recorded on the record sheet. Examination of physical condition was made by loosening the outer boards and the thread (if available) of the palm-leaves and the leaves of the manuscripts randomly checked. The brittleness of the leaf was identified by touching the leaf and the pagination order of the manuscript was checked by using the 544 signs and the Lith lakunu which were used in paginating manuscripts by W. A. de Silva. (De Silva, 1938). Temperature and Relative Humidity were recorded by using thermo hygrometer placed in the stack area and for three months thermo hygrograph readings were analysed.

The available preservation and conservation methods, preservation programmes, training, and workshops held in these repositories were identified through interviews with the staff of the conservation units.

\section{Analysis of data}

Data was analysed by using the Statistical Package for Social Sciences (SPSS). The analysis included the tabulation of data of deterioration and the physical condition of the collections and cross tabulation of variables to determine the connection between environmental conditions and the physical condition of the manuscripts and deterioration of the leaves. 


\section{Results and Discussion}

\section{Practical problems faced in maintaining the collections.}

Considering the present condition of the collections, all these 3 repositories face the practical problems when maintaining the collections. which are directly affect the management. Lack of equipment, lack of trained staff, lack of time, limited allocation of funds and lack of training programmes were the common problems to all the repositories and only two repositories (NM \& UP) face lack of space to maintain the collections. UP repository faces highest number of problems in the area of maintenance of palm-leaf collection. With these problems the staff proposed the following solutions and actions to overcome same. All three repositories have mentioned that, by increasing trained staff, allocation, equipment, and chemicals the problems could be fulfilled. In addition to these, the necessity of space and establishment of laboratories are the considerable problems for NM \& UP repositories. O. P. Agrawal (1999) stated that, "it was observed that there were not many persons trained in the technique of conservation of palm-leaf manuscripts. This was true not only for India but for all other countries of Asia".

In addition to that, the research revealed that the following defects are also common to all the collections, such as dust, insects and lack of wooden boards for manuscripts. At the same time, NM \& UP repositories have defective manuscripts. Beside that UP repository faces difficulties due to lack of expertise for identifying and reading manuscripts.

\section{Storage systems of the repositories}

A large amount of the collections are stored in glass or wooden cupboards in the NM repository and 36 manuscripts are wrapped in yellow and red mixed cloth. The UP repository, all the manuscripts are stored in specially made wooden drawers. The collection in NA is scattered every where and some were wrapped in paper. All the collections are arranged systematically and none of the collections have followed the de-stack method. Only 25 manuscripts have been stored vertically in the NA repository due to lack of storage space and others are stored horizontally.

\section{Flaws of palm leaves (Deterioration)}

In preservation of manuscripts, environmental background and physical facilities are important requirements for the preservation activity. The background of the repositories in which these manuscripts are kept was studied, and prevailing storage conditions, dustless, less polluted environment of the stack area, cleaning, lighting, ventilation, maintenance of optimum temperature and relative humidity were studied. The survey, by Yapa (1994) relating to the preservation of library materials, "revealed that none of the libraries (university libraries) had 
written preservation policy statements" and still this is valid to whole of the country.

All the flaws of palm-leaves were examined and Table 1 presents the percentages of the highest no. of stains(17.02\%), fungi(27.65\%) and average $\mathrm{RH}$ within the period of study is $80.46-82.41 \%$ in the UP repository, insect damage $(29.58 \%$ ) and water damage of the palm-leaves, due to non availability of air condition in the NM repository. Surface discoloration has happened due to the lighting system $(48.93 \%)$ of these repositories and it was cross tabulated comparing with two variables of the survey. "Because of chemical and physical action started by light, disintegration of cellulose fibres and other constituent elements which generally results in discolouration and embrittlement of leaves starts". (Prajapati, 1996). This revealed the important factor of the difference of controlled and uncontrolled characteristics of the environment.

Table 1 The flaws of the palm-leaf manuscripts which were observed within three repositories

\begin{tabular}{|c|c|c|c|c|c|c|c|c|}
\hline $\begin{array}{l}\text { Repo } \\
\text { sitory } \\
\text { Num } \\
\text { ber }\end{array}$ & $\mathbf{N}$ & $\begin{array}{l}\text { Availability } \\
\text { of } \\
\text { Air- } \\
\text { condition }\end{array}$ & Stains & $\begin{array}{l}\text { Presence of } \\
\text { Fungi }\end{array}$ & $\begin{array}{c}\text { Insect } \\
\text { damage }\end{array}$ & Vater stains & $\begin{array}{l}\text { Light } \\
\text { Fluores } \\
\text { cent } \\
\text { Incand } \\
\text { escent }\end{array}$ & $\begin{array}{l}\text { Surface Dis- } \\
\text { colouration }\end{array}$ \\
\hline NM & 382 & $\begin{array}{l}\text { Air- } \\
\text { conditioned } \\
\text { Not air- } \\
\text { condiitioned }\end{array}$ & $\begin{array}{c}- \\
44-11.514 \\
(382)\end{array}$ & $\begin{array}{c}- \\
12-3.14^{\prime \prime}, 1 \\
(382)\end{array}$ & $\begin{array}{c}- \\
113-29.58 \% " 1 " \\
(382)\end{array}$ & $\begin{array}{c}-7.83 \% \\
(382)\end{array}$ & $\begin{array}{c}- \\
\text { Fluorescent }\end{array}$ & $\begin{array}{r}140-36 .(34 \% \\
(382)\end{array}$ \\
\hline UP & 232 & $\begin{array}{l}\text { Air- } \\
\text { conditioned } \\
\text { Not ait- } \\
\text { conditioned }\end{array}$ & $\begin{array}{c}32-17.02 \% \\
(188)\end{array}$ & $\begin{array}{c}52-27.65 \% \\
(188)\end{array}$ & $\begin{array}{c}4-9.09 \% \\
(44) \\
48-25.53 \% \\
(188)\end{array}$ & $\begin{array}{c}- \\
4-1.72 \% \\
(232)\end{array}$ & $\begin{array}{l}\text { *Fluorescent } \\
\text { Fluorescent }\end{array}$ & $\begin{array}{r}6-13.63 \% \\
(44) \\
92-48.93 \% \\
(188)\end{array}$ \\
\hline NA & 103 & $\begin{array}{l}\text { Air- } \\
\text { conditioned } \\
\text { Nol dir- } \\
\text { conditioned }\end{array}$ & $\begin{array}{c}7-6.79^{\circ} \% \\
(103)\end{array}$ & $\begin{array}{c}5-4.85^{\circ} \\
(103) \\
-\end{array}$ & $\begin{array}{c}19-18.44^{\circ} \\
(103)\end{array}$ & $\begin{array}{c}2-1.94 \% \\
(103)\end{array}$ & *Fluorescent & $\begin{array}{c}22-21.35^{\circ} \\
(103) \\
-\end{array}$ \\
\hline Total & 717 & & & & & & & \\
\hline
\end{tabular}




\section{Physical condition of the leaves}

According to the Table 2, it is also clear that some flaws had happened due to the non availability of air conditioning in these repositories. Split or peeling of the surface $(20.74 \%)$, brittleness $(19.68 \%$ ), leaves rigid/flexible $(12.76 \%)$ had been caused due to wide variations in temperature and moisture in the environment. (Agrawal, 1984 \& Kishore, 1962). At the same time, due to non availability of dehumidifiers, the condition of humidity is high (Agrawal, 1984) and required amount is not controlled. It was revealed that leaves stuck together $(11.20 \%)$ and cleavage of its surface $(8.11 \%)$ had happened because many are stored in bundles.

Table 2 Physical conditions of the leaves in different environment in these three repositories

\begin{tabular}{|c|c|c|c|c|c|c|c|c|}
\hline $\begin{array}{c}\text { Repos } \\
\text { itory } \\
\text { No. }\end{array}$ & $\mathbf{N}$ & $\begin{array}{c}\text { Availabili } \\
\text { ty of } \\
\text { Air- } \\
\text { conditio } \\
n\end{array}$ & $\begin{array}{l}\text { Split of } \\
\text { peeling } \\
\text { on the } \\
\text { surface }\end{array}$ & Brittleness & $\begin{array}{l}\text { Leaves } \\
\text { Rigid }\end{array}$ & $\begin{array}{l}\text { Availability of } \\
\text { De-humidifiers }\end{array}$ & $\begin{array}{l}\text { Stuck } \\
\text { Leaves }\end{array}$ & $\begin{array}{c}\text { Cleavag } \\
e \\
\text { of } \\
\text { surface }\end{array}$ \\
\hline NM & 382 & $\begin{array}{l}\text { Air- } \\
\text { condition } \\
\text { ed } \\
\text { Not Air- } \\
\text { condition }\end{array}$ & $\begin{array}{l}- \\
72-18.84 \% \\
(382)\end{array}$ & $\begin{array}{l}- \\
\\
19-4.97 \% \\
(382)\end{array}$ & $\begin{array}{c}- \\
8-2.09 \% \\
(382)\end{array}$ & $\begin{array}{l}\text { De-humidifiers } \\
\text { No De- } \\
\text { humidifiers }\end{array}$ & $\begin{array}{l}- \\
34-8.90 \% \\
(382)\end{array}$ & $\begin{array}{c}- \\
31-.11 \% \\
(382)\end{array}$ \\
\hline UP & 232 & $\begin{array}{l}\text { Air- } \\
\text { condition } \\
\text { ed } \\
\text { Not Air- } \\
\text { condition }\end{array}$ & $\begin{array}{c}4-9.09 \% \\
(44) \\
\\
39-20.74 \% \\
(188)\end{array}$ & $\begin{array}{l}2-4.54 \% \\
(44) \\
37-19.68 \% \\
(188)\end{array}$ & $\begin{array}{c}3-6.81 \% \\
(44) \\
\\
\\
24-12.76 \% \\
(188)\end{array}$ & $\begin{array}{l}\text { De-humidifiers } \\
\text { No De- } \\
\text { humidifiers }\end{array}$ & $\begin{array}{l}- \\
26-11.20 \% \\
(232)\end{array}$ & $\begin{array}{c}- \\
18-.75 \% \\
(232)\end{array}$ \\
\hline NA & 103 & $\begin{array}{l}\text { Air- } \\
\text { condition } \\
\text { ed } \\
\text { Not Air- } \\
\text { condition }\end{array}$ & $\begin{array}{c}15-4.56 \% \\
(103)\end{array}$ & $\begin{array}{l}2-1.94 \% \\
(103)\end{array}$ & $\begin{array}{l}6-5.82 \% \\
(103)\end{array}$ & $\begin{array}{l}\text { De-humidifiers } \\
\text { No De- } \\
\text { humidifiers }\end{array}$ & $\begin{array}{l}2-1.94 \% \\
(103)\end{array}$ & $\begin{array}{c}5-4.85 \% \\
(103)\end{array}$ \\
\hline Total & 717 & & & & & & & \\
\hline
\end{tabular}


The basic requirements for properly storing of the palm-leaf manuscripts are the wooden boards and cotton yarn. These would help to protect the manuscripts to a certain extent from most defects. Table 3 has shown that damages like tearing, breaking of edges had happened due to the non availability of these basic requirements such as wooden boards and cotton yarn. All the manuscripts may not require elaborate conservation treatment, but all of them would require basic cleaning and slight rearrangement and renewal of strings and binding cloth. The manuscript covers have to be treated if they have suffered damage. (Harinarayana, 1996)

Table 3. Flaws which happen due to non availability of basic requirements.

\begin{tabular}{|c|c|c|c|c|c|c|}
\hline $\begin{array}{l}\text { Repository } \\
\text { No. }\end{array}$ & $\mathbf{N}$ & $\begin{array}{c}\text { Status of } \\
\text { need boards }\end{array}$ & $\begin{array}{l}\text { Need } \\
\text { Cotton } \\
\text { yarn }\end{array}$ & Torn & $\begin{array}{l}\text { Edges } \\
\text { damaged }\end{array}$ & $\begin{array}{c}\text { Total } \\
\text { need \& } \\
\text { no need } \\
\text { boards }\end{array}$ \\
\hline \multirow{3}{*}{ NM } & \multirow{3}{*}{382} & No need & \multirow{2}{*}{$\begin{array}{l}8(2.23 \%) \\
21(87.5 \%)\end{array}$} & \multirow{2}{*}{$\begin{array}{c}90(25.13 \%) \\
14(58.33 \%)\end{array}$} & \multirow{2}{*}{$\begin{array}{r}78(21.78 \%) \\
12(50 \%)\end{array}$} & 358 \\
\hline & & $\begin{array}{c}\text { Need boards } \\
=\end{array}$ & & & & $\begin{array}{c}24 \\
(6.28 \%)\end{array}$ \\
\hline & & $\begin{array}{c}\text { Total } \\
\text { Torn }=\end{array}$ & $\begin{array}{l}29(7.59 \%) \\
(23.56 \%)\end{array}$ & $104(27.22 \%)$ & 90 & 382 \\
\hline \multirow[t]{3}{*}{ UP } & \multirow[t]{3}{*}{232} & $\begin{array}{l}\text { No need } \\
\text { boards = }\end{array}$ & \multirow{2}{*}{$\begin{array}{l}14(9.65 \%) \\
(41.37 \%)\end{array}$} & $\begin{array}{r}7(8.04 \%) \\
34(23.44 \%)\end{array}$ & $\begin{array}{c}14(16.09 \%) \\
60\end{array}$ & 87 \\
\hline & & $\begin{array}{c}\text { Need boards } \\
=\end{array}$ & & & & $\begin{array}{l}145 \\
(62.5 \%)\end{array}$ \\
\hline & & $\begin{array}{c}\text { Total } \\
\text { Torn }=\end{array}$ & $18(7.75 \%)$ & $41(17.67 \%)$ & $74(31.89 \%)$ & 232 \\
\hline \multirow{3}{*}{ NA } & \multirow[t]{3}{*}{103} & $\begin{array}{l}\text { No need } \\
\text { boards = }\end{array}$ & $\begin{array}{l}20(21.05 \%) \\
6(75 \%)\end{array}$ & \multirow[t]{2}{*}{$\begin{array}{c}26(27.36 \%) \\
4(50 \%)\end{array}$} & \multirow[t]{2}{*}{$\begin{array}{c}16(16.84 \%) \\
\mathbf{3}(\mathbf{3 7 . 5 \% )}\end{array}$} & 95 \\
\hline & & $\begin{array}{c}\text { Need boards } \\
=\end{array}$ & & & & $8(7.76 \%)$ \\
\hline & & $\begin{array}{c}\text { Total } \\
\text { Torn }=\end{array}$ & $\begin{array}{l}26 \\
(25.24 \%)\end{array}$ & $3(29.12 \%)$ & $19(18.44 \%)$ & 103 \\
\hline Total & 717 & & 73 & 175 & 183 & 717 \\
\hline
\end{tabular}

Table 4 presents the rest of the physical damages which had been observed in this research such as fading of writing, curling of leaves, flaking, not blackened, 
pagination disorder and the manuscripts needed repairing. It was depicted that, lack of conservation units were a major weakness in some repositories, and this specially is pertaining to UP repository. All these damages are depicted in figure 1

Table 4. Flaws which happen due to lack of proper maintenance

\begin{tabular}{|c|c|c|c|c|c|c|c|}
\hline $\begin{array}{c}\text { Repository } \\
\text { No. }\end{array}$ & $\mathbf{N}$ & $\begin{array}{c}\text { Fading } \\
\text { of } \\
\text { Writing }\end{array}$ & $\begin{array}{l}\text { Leaves } \\
\text { Curled }\end{array}$ & Flaking & $\begin{array}{c}\text { Not } \\
\text { Blackened }\end{array}$ & $\begin{array}{l}\text { Pagination } \\
\text { Disorder }\end{array}$ & $\begin{array}{l}\text { Leaves } \\
\text { To be } \\
\text { repaired }\end{array}$ \\
\hline NM & 382 & $\begin{array}{c}21 \\
(5.49 \%)\end{array}$ & 2 & 2 & 3 & $83(21.72 \%)$ & $\begin{array}{l}150 \\
(39.26 \%)\end{array}$ \\
\hline UP & 232 & $\begin{array}{c}29 \\
(12.5 \%)\end{array}$ & 5 & 3 & 5 & $22(9.48 \%)$ & $\begin{array}{l}145 \\
(62.5 \%)\end{array}$ \\
\hline NA & 103 & $\begin{array}{c}6 \\
(5.82 \%)\end{array}$ & 3 & 5 & 3 & $20(19.41 \%)$ & $\begin{array}{c}30 \\
(29.12 \%)\end{array}$ \\
\hline Total & 717 & 56 & 10 & 10 & 11 & 125 & 325 \\
\hline
\end{tabular}

Figure 1- Physical condition of the palm-leaves.

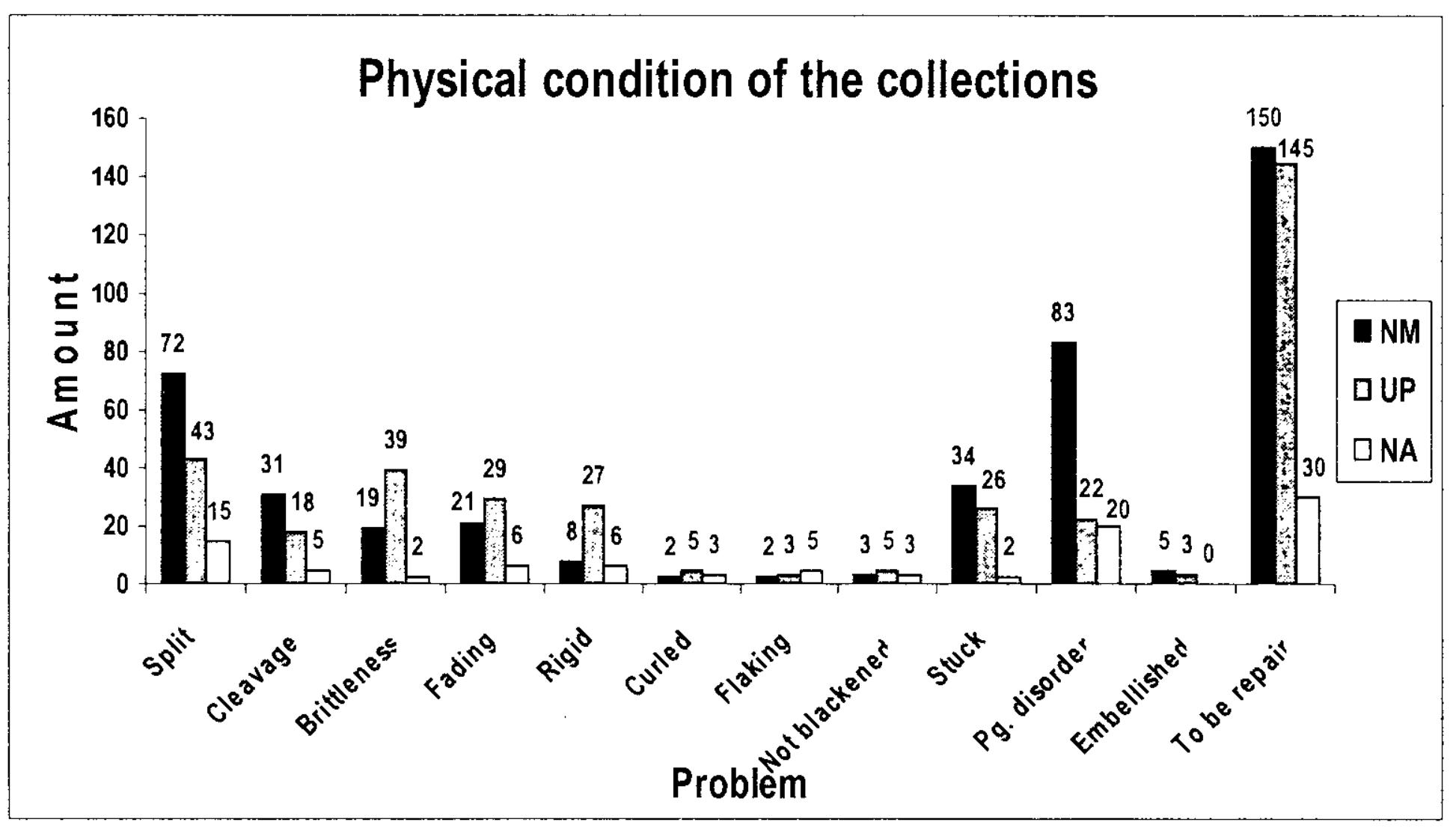




\section{Conservation problems in repositories}

Repairing palm-leaf manuscripts is a specialized job which requires well trained staff, precise equipment, chemicals and conservation units. The survey revealed that, only two repositories are equipped with conservation units(NM \& NA) within their institutions and the UP repository has no conservation unit of their own but have a binding unit which attends to repair work of the monographs and other paper documents. Though, the NM repository has 09 members of the staff to attend to the repairs full-time, the cadre positions of the staff and the trained staff are not sufficient to fulfill the conservation work load of the repository. The NA repository has mentioned that, they have 34 staff and all the members attend fulltime to all kinds of conservation and preservation work when necessary inside the repository and all are trained for the work within the institution.

According to the survey, no modern conservation techniques are applied for palm-leaf manuscripts in UP repository in Sri Lanka due to lack of knowledge in modern techniques. Further, the NM \& NA repositories have acquired equipment which are needed to conserve the palm-leaves and the UP repository has some, which are also used in the binding unit. In addition, the NM \& NA repositories have mentioned that, some of the equipment which are needed are costly. Since the present financial constraints, priority should be given for the most essential requirements in these repositories than to purchase costly equipment.

\section{Existing preservation programs}

The staff of the NM and the NA repositories have undergone preservation and conservation training in several places. National Library and Documentation Services Board (N.L.D.S.B.) have conducted short demonstrations on the preservation of palm-leaf collections and some of the members have participated for the short term demonstration in the year of 2001. Most of the staff in these two repositories (NM \& NA) have obtained their training in modern techniques of conservation of palm-leaf from "The Indian National Trust for Art and Cultural Heritage -Indian Conservation Institute" (INTACH- $\mid \mathrm{Cl}$ ) at Bhubaneswar, Orissa, in 1999, 2000, 2001 and 2002, in addition to the local experiences. Every year 4 months training programmes have been organised by this institution and it has provided theoretical as well as practical training on the modern techniques of preservation and conservation of palm-leaf manuscripts. The participants made to understand that, it has provided enough practical training during the course and more concerned about the modern techniques of conservation of palm-leaf manuscripts rather than the traditional oiling method. One member of the UP repository had got training for the blackening of palm-leaves from professionals in traditional Aluvihara Temple as they use traditional method of blackening and oiling to preserve the manuscript collection. In addition to that, all 3 repositories have provided blackening and oiling in figure 2 and the basic requirements specially, restrung the manuscripts. The staff made to understand that, provision of wooden boards is still stagnating due to lack of funds. Therefore, thin cardboard covers are used for the protection of manuscripts. At the same time, 
the NM repository has stated that, they have consulted INTACH-ICI institution in India when a problem arises. In addition to that, they get advice from Department of National Archives - Sri Lanka and the expertise in the field. The UP repository has stated that they have not requested assistance from any organization. The NA repository has stated that it is in possession with the expertise in the field of preservation and they are capable to preserve almost all the documents in the country including palm-leaf manuscripts.

Figure 2- Oiling of palm-leaves in the 3 repositories.

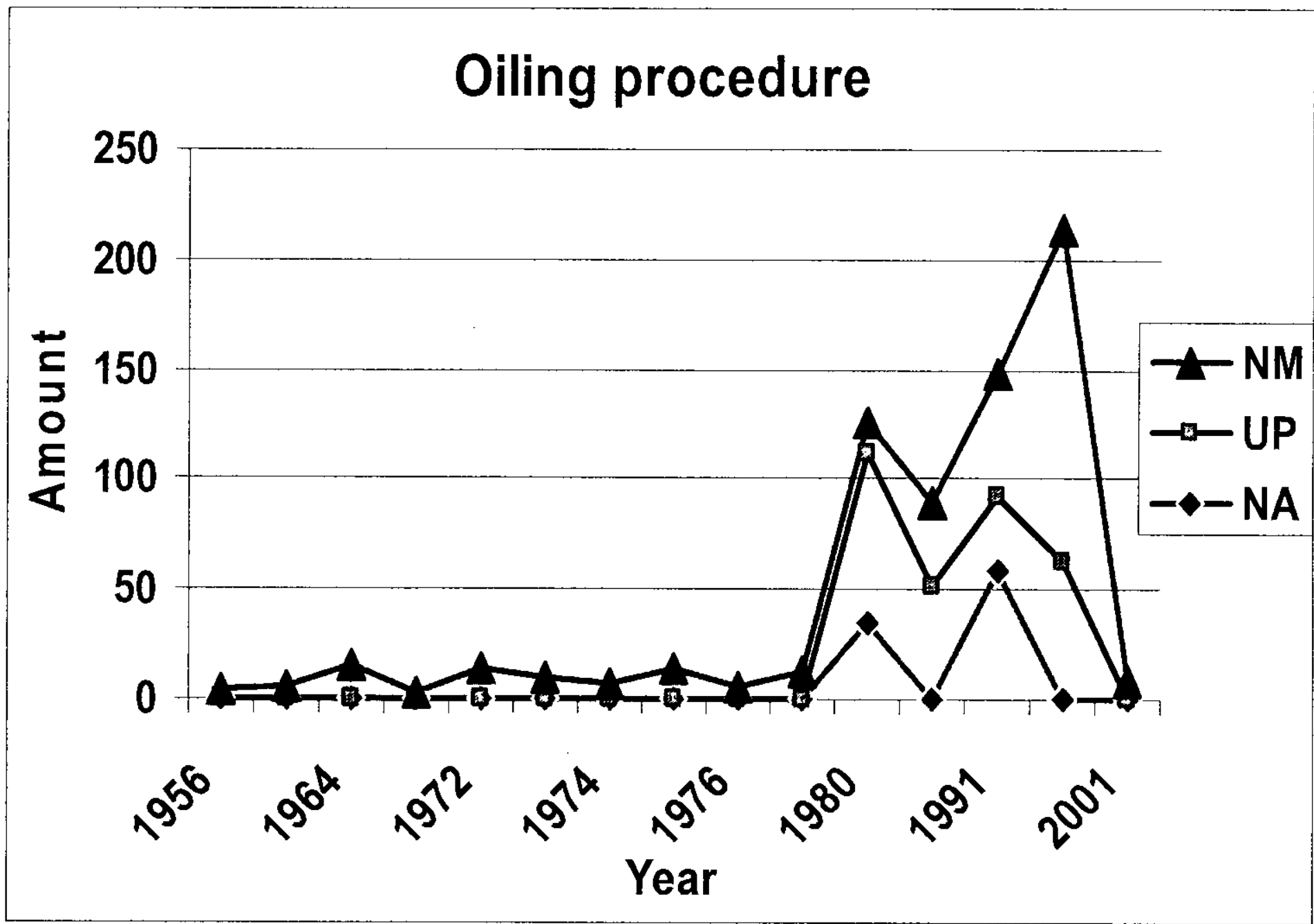




\section{Suggestions to minimize the problems}

The study revealed that, nationally and institutionally, the preservation departments need to be established to undertake some of the preventive measures immediately to prevent further damage of the collection specially, airconditioners, de-humidifiers, suitable lights for the storage areas and basic requirements such as boards and yarns for the manuscripts. As an alternative, the cover boards can be made by using the acid free thick boards $\mathrm{PH} \cdot 6.6$ and also instead of cotton yarns, the nylon string could be used. Though Crowley (Crowley, 1969) has introduced the lamination method, it may not be applicable in Sri Lanka repositories, as the process has had effects on the palm leaves in tropical countries. The paraprofessional staff should be properly trained at all levels in this unit or it should have one person designated as an officer in-charge to address the preservation and conservation activities in the repository and s/he should have to obtain a thorough technical knowledge of conservation including handling sophisticated machinery, equipment and tools, microfilming, identification and reporting of damages. A formal well prepared preservation policy statement should be formulated to provide the guidelines to implement the preservation programmes of the collections.

The storage should be designed not to disturb other manuscripts while retrieving one and need to be kept individually and should need to provide the written bibliographic details of the manuscripts. General cleanliness, awareness, tidiness and periodic inspections should be carried out in the storage areas of the repositories. Ascertain the temperature, humidity and air quality, lighting, dust and pollution levels of the storage areas and should provide sufficiently detailed overview of the collections. Every repository should undertake at least one fumigation method to destroy all traces of micro-organisms fungal and insect growth. Thymol could be used for fungi with caution and Red Earth aqua fumigant (Pyrethroid) could be used for insects.

It requires to implement the advisory services and the management and it should need a joint venture between the librarians, archivists and the technicians of the repositories. In Sri Lanka the expert personnel are available in the Department of National Archives which is the premier institution specialized in the country for conservation of materials.

\section{Conclusion}

Digitization is mentioned as a future dream of these repositories. Though, these three repositories have practiced the microfilming as a means of preservation of the palm-leaf collections, some of the repositories have no facilities of reader printers to make use of microfilmed reels of the manuscripts and to obtain the copies of them. 
There are certain factors needed to overcome these preservation requirements. They are financial availability, trained personnel, sufficient equipment, availability of facilities, enough know-how of the modern methods and established preservation policies for these repositories.

\section{References}

Agrawal, O.P. (1984). Conservation of manuscripts and paintings of South-east Asia Butterworths Series in Conservation and Museology. Butterworths : Butterworth \& Co.

Agrawal, O.P. (1999). Towards conservation of palm-leaf manuscripts Bulletin no. 25.

Amarakoon, Lionel R. (1996). National Museum Library of Sri Lanka: It's resources and services. Sri Lanka Library Review 10, no. 1/2.

Crowley, Alfred S. (1969) Repair and conservation of palm-leaf manuscripts Restaurator 1, no. 1.

De Silva, W.A. (1938). Catalogue of Palm Leaf Manuscripts in the Library of the Colombo Museum. Memoirs of the Colombo Museum Series A. No. 4 vol. 1 Colombo: Ceylon Government Press.

Harinarayana, N. (1996). Techniques of conservation of palm-leaf manuscripts: Ancient and modern in Palm-leaf and Other Manuscripts in Indian Languages: Proceedings of the National Seminar Session Held in Pondicherry University 1113 January 1995, ed. Shu Hikosaka and G. John Samuel, India : Institute of Asian Studies.

Kishore, Ranbir (1962). Preservation and repair of palm-leaf manuscripts The Indian Archives 14, January 1961-December 1962.

Prajapati, C.L. (1996). Modern techniques on conservation of palm-leaf manuscripts in palm-leaf and other Manuscripts in Indian Languages: Proceedings of the National Seminar Session held in Pondicherry University 1113 January 1995, ed. Shu Hikosaka and G. John Samuel, India : Institute of Asian Studies.

Wickremaratne, K.D.L. (1967) Palm Leaf Manuscripts of Ceylon. Ceylon Today 16, no. 1 January : 21.

Yapa, A.G.S. (1994) Preservation of library materials : with special reference to University Libraries in Sri Lanka. Unpublished M.L.S. thesis University of Colombo 
